\title{
Instruments of Surveillance Welfare: Computerizing Unemployment and Health in 1960s and 1970s Sweden
}

\author{
Isabelle Dussauge $^{1}$ and Julia Peralta ${ }^{2}$ \\ ${ }^{1}$ Dept. of Thematic Studies - Technology and Social Change \\ Linköping University, 58183 Linköping, Sweden \\ isabelle.dussauge@liu.se \\ ${ }^{2}$ Swedish Institute for Disability Research \\ Örebro University, 70182 Örebro, Sweden, and \\ Div. of History of Science and Technology, KTH \\ 10044 Stockholm, Sweden \\ julia.peralta@oru.se
}

\begin{abstract}
The object of this paper is the role of computerization in the establishment of a specific form of "surveillance welfare" after World War II. Was computerization used as a technology of mass-welfaring to produce a governable population in the frame of an expanding welfare state? Large-scale welfare practices such as health screenings and databasing of the unemployed seem to have a common purpose: making the population into a governable, partially self-regulating, collective body-a welfare body. The paper analyzes the use of computers in the implementation of regional health screenings in the 1960s and the 1970s and in the transformation of (un)employment procedures in the 1970s as two sites for the exercise of state control in post-WWII Sweden.
\end{abstract}

Keywords: Control, health screenings, history, unemployment policy, welfare.

\section{Introduction}

In line with many other sectors, the Swedish public administration introduced computerized applications in the 1960s. The post-WWII industrial growth had led to a tremendous expansion of the public sector and services. Computers made possible a breakthrough in data processing and they became an important tool in the rationalization of administrative tasks. For the public administration, they became instruments for the control of welfare procedures. Decision-makers (politicians and civil servants) saw computerization as a way to eliminate loopholes in the tax and social insurance systems and to enhance welfare services. One major aspect of these developments was the establishment of computed systems for the production and classification of data covering the population [1-3].

From Discipline and Punish through History of Sexuality (1977-1984), the French philosopher Michel Foucault inquired into the emergence and installation of modern and postmodern means of societal control, which he refers to as surveillance. These 
forms of control did not always explicitly derive from concrete policies or political measures; instead, they were indirect and exerted by means of disciplining technologies through which individual and collective bodies/subjects were rendered manageable and compliant to societal orderings. Here, health care system and labor market policies are considered as two such instances of surveillant control of the population.

This paper will explore two cases in the use of computerization in the expansion and/or strengthening of two welfare institutions: health screenings as an instance of public health and employment agencies as an instance of labor market policies. In our conclusions, we will come back to the following two questions: Which were the goals of computerization in these two instances of the Swedish welfare system? How did the computerization of these welfare practices possibly affect the definition of the social problems (unemployment, health), which they were used to manage?

\section{Automating the Collective Body: The Värmland Screening}

In Sweden, health care policy and services as well as the National Board of Health (Medicinalstyrelsen) have had a central place in the establishment and post-WWII expansion of the Swedish welfare system. The Värmland Mass Screening Pilot Program $^{1}$ was initiated by the National Board of Health and started in 1962. This was the first time in Sweden a health control was conducted that was conceived as a total screening, encompassing a whole geographical population and seeking to identify a large battery of possible diseases with the help of automated and computerized technologies.

In 1948, a governmental committee led by the Director-General of the Swedish Medical Board, Axel Höjer, released a major government report on outpatient care, which had been described as Höjer's political legacy. In this document, Höjer argued that the focus of public health care services should be to maintain the population's health and prevent diseases, rather than focusing on the treatment of known diseases, thus continuing a trend that in Sweden had emerged in the 1930s [4]. The 1948 report also recommended that public authorities conduct a series of pilot screenings [5]. It was not until in 1961 that the Board of Health received its first governmental funding for a pilot program [försöksverksamhet] of general health control "on a larger scale" [6].

The Board referred later to the lack of doctors in Sweden in the 1950s as the reason why the large-scale health screenings had to wait [6]. In hindsight, the Board also wrote that "the classification of the healthy [and sick] among the people examined" had to be done "without concrete participation of a doctor. We considered that this condition was fulfilled by the development achieved in clinical-chemical laboratory technology" [7].

\subsection{Technologies of Mass-Screening}

The Board of Health decided that the main screening instrument in the Värmland screening would be automated blood chemical analysis, i.e. the use of an automated

${ }^{1}$ Allmän hälsokontroll $i$ Värmlands län, försöksversamhet - here referred to in short as the Värmland Screening. 
apparatus conducting a pre-defined range of chemical analyses of blood samples. More precisely, the Board recruited the services of clinical chemist Gunnar Jungner's and doctor Ingmar Jungner's new automated laboratory, MEKALAB [7]. The Jungners were largely inspired by growing visions of mass screening at the US American National Institute of Health in the late 1950s where Gunnar Jungner had spent a sabbatical in 1959-1960. By 1961, the Jungners had designed automated machinery for chemical analysis of large amounts of blood samples [8].

Whereas Höjer's 1948 report argued for a yearly health control of everyone aiming at a healthy and well-informed population, the goals of the Värmland Screening were, in comparison, more modest. By the 1960s, the agenda was reduced to test the value of the specific screening method as a way to identify sick and diseased patients $[5,9]$. In a nutshell, the argument for this was that common diseases could be identified in patients before they themselves felt the symptoms [5, 10]. Early detection of diseases was argued to be an instrument for the health authorities to better fight diseases and make health care services, as a whole, more effective by referring patients to a larger extent to primary health care [5].

Forty years later, Ingmar Jungner explained that "[t]he Värmland Screening could be considered an extreme attempt to conduct a mass screening in an effective manner" [8]. The Värmland Screening was "planned as a methodological study in order to determine if chemical blood analysis can be used as a method for mass screening ... in a general health control in the same way as x-ray examination [tuberculosis screenings]." Ivar Friman, a doctor centrally involved in the Board of Health's coordination of the Värmland Screening, also indicated that the criteria of assessment of the method would be not only the medical results of the screening but also the costs of blood-chemical testing as a method for screening. Further, Friman described the Jungners' "automated laboratory" as "precondition in order to conduct a health control of the [Värmland Screening] kind for an acceptable cost" [9]. Balancing health results and costs was an organizational equation that was not specific to the Värmland Screening, as witnessed by documents on other health controls in planning during the first half of the $1960 \mathrm{~s}$ (which awaited the conclusions from the Värmland Screening) [11].

Thus, although improving the population health was a general long-term rationale for the large-scale health controls, such screenings were not only aimed at controlling health but also at controlling the costs of the publically funded health services and their use of personnel resources. The Värmland Screening was an assessment of a certain kind of infrastructure and automatized laboratory for this job.

\subsection{Computers in a Socio-Technical System of Control}

The Värmland screening started on 1 October 1962 in the area of Arvika with the official goal to examine about 100,000 inhabitants in a three-year period [9]. "Among the 88,959 who were screened, 7,620 (8.6 percent) were singled out and sent to follow-up control with examination by a doctor. Among those, previously unknown disease was identified in 3,014 individuals," Ingmar Jungner writes [8].

The Värmland Screening marked the Board of Health's implementation of a massscale infrastructure designed to mobilize, examine, screen and potentially treat a whole population, a collective body. Huge amounts of work were required to make the infrastructure work, along three dimensions: 
Firstly, it mobilized the collective body of the population. The Värmland Screening created and relied on a large-scale organization reaching all the way down to the population with the creation of "local committees" in each municipality, whose role was to attempt to achieve 100 percent participation of the population. In some organizational aspects (e.g. producing lists of people to call in to the screening), the Värmland Screening was drawing on an existing structure of x-ray screening for tuberculosis. The administration of calling in the population was computerized, and the participants were registered with their "national identification number" (date of birth).

Secondly, at the core of the screening procedure were the production and analysis of health data on the participants. A Central Committee and the municipalities shared the responsibility to arrange rooms, personnel, instruments and standardized procedures for physical examination and the taking of samples for laboratory examinations. Blood samples were sent to MEKALAB, where the Jungners' automated apparatus was made to perform a huge number of analyses of bodily fluids.

Thirdly, the data produced on the health of the participants had to be analyzed for each participant in order to decide who should be contacted for a more thorough medical examination. In the first year of the Värmland Screening, doctors and subsequently automated through computerized processing conducted centrally this preliminary screening decision. Concretely, a program that identified abnormal values interpreted the health data of each participant. Data cards with abnormal values were sent to the central medical assessment group of the Värmland Screening that "made a judgment" and categorized patients for further referral [12]. The purpose of this computerization was to minimize the involvement of doctors, for two reasons: to minimize the amount of errors (in the identification of samples and data; in the originally manual transposition of data values; and in the identification of abnormal data for further medical interpretation); and to use personnel efficiently. ${ }^{2}$

\subsection{Interpretation: Controlling the Cost of Health Screenings}

The Värmland Screening was part of a historical shift in medical regimes in the Western world: from managing the sick to monitoring the healthy [13]. In that sense, computerization and automation were part of the historical installation of surveillance medicine and its qualitatively new object: health and healthy populations.

Although the Värmland Screening in many ways was a technical and organizational success (it worked, people participated to a large extent, diseases were diagnosed in patients), it was finally evaluated as evidence against mass-scale general screenings. Such general screenings were dismissed as a general tool for health monitoring of the population because they were too demanding on health care resources: costs and personnel; and their clinical value was therefore questioned [5]. This illustrates that the function of the ideal screening was not so much to control population health but rather to control the costs and organization of producing population health.

However, new pilot screenings were generated in the dawn of the Värmland Screening. According to a later governmental report, the debates that arose around the

\footnotetext{
${ }^{2}$ Additionally, the computerized processing was supposed to enable sorting the newly archived screening data by birth date (folkbokföringsnummer) - thus opening up for easier retrieval of data.
} 
Värmland Screening triggered many counties and municipalities to plan and conduct their own screening programs. ${ }^{3}$

\section{Matching Labor Supply and Demand: Computerization of Employment Agencies}

The computerization of the Swedish public employment services began in the late 1960s, divided into three phases. A first phase involved the development of all administrative systems. The second phase came to focus on the application of computer resources to the placement process, i.e. the service in which the unemployed were offered work positions that suited their competence profile. The third and final phase consisted in the construction of a totally integrated information management system. In the present text we inquire on the second phase and, more specifically, on the computerization of the placement work of the Swedish employment agencies in the period 1968-1984. The application of computer technology in the employment agencies became an important instrument in their efforts to achieve social policy goals, which in turn were closely related to the government's key socio-economic objectives [14].

On 6 November 1972, the National Labor Market Board (Arbetsmarknadsstyrelsen, AMS) appointed a working group named $A M S$-ADB-utredning [15], who identified a few main problems in the functioning of the labor market. The average length of periods of unemployment and the vacancy times (the time when an available position is unoccupied) had become longer in comparison with earlier periods with similar conditions of overall demand for labor. Moreover, by the early 1970s, there were large regional, sectorial and social disparities in unemployment and labor supply. The participation of women in the labor force had increased, whereas the overall employment rate had decreased; young as well as older people experienced more difficulties in employment. Regional disparities in unemployment rates and shortages of high-skilled workforce were evident [14].

The employment services envisaged computerization as a means to implement two main strategies: the production and analysis of better information on the labor market, and the improved placement of the unemployed based on this information. With these two strategies, they aimed to solve the problems connected with periods of unemployment, vacancy times, and disparities in labor supply and demand [14]. By exploring these strategic improvements in information and placement, we aim to shed light on the rationale of the computerization of employment services.

\subsection{ADB in the Employment Service}

In the 1970s and until 1984, three interdependent projects dominated the computerization of the employment services: Creation of job listings (platslistor); development of a search engine (terminalsökning) and a matching engine (bevakningsmatchningen); and finally a pilot employment agency (modellkontor). The last two projects had an experimental character and they were followed up regularly during the period studied.

\footnotetext{
${ }^{3}$ About fifteen health screening projects were conducted in Sweden on different scales between 1963 and 1978, to be compared to five projects until 1962, see [16].
} 


\subsection{Job Listings}

In December 1971, a pilot project of computerized production of daily job listings was launched in Stockholm. The job listings were easily produced, and they were introduced in Gothenburg in 1974-75 and later in Malmö. AMS-ADB-utredning suggested a rapid expansion of computerized job lists all over the country. The AMS$A D B$-utredning settled in its first report, published in 1974, that the simple job listings would be replaced by computerized regional job listings in tabloid format, which would be produced using computer graphic techniques [15]. The information on each job became more extensive and more clearly structured which was an improvement in relation to the previous system [17].

\subsection{Search Engine and Matching Engine}

In its first report, the $A M S-A D B$-utredning suggested the introduction of terminals for searching and matching to achieve greater effectiveness in the placement process. ${ }^{4} \mathrm{~A}$ comprehensive and well-structured job database was developed in connection with the computerized production of job listings, which at that time were produced in nineteen counties. The job database stored and made available computerized information on vacant jobs, which was a central prerequisite for testing the search engines and matching engines [17].

During the study period, the scope of the search and matching engine projects gradually expanded to include 158 terminals, located at some 90 employment offices, each terminal shared between several employment agency officers [14]. These computer-based tools were adequate and they brought an improvement in the quality of job placement. The opinion of the employment office staff was that terminals "gave a better overview of the labor market and helped them activate the unemployed" [14].

\subsection{Pilot Agency}

The third operation consisted in developing two instances of a "pilot employment agency," carried out in two employment services districts in Södermanland. It started in 1980. The pilot projects aimed to test the implementation of organizationally and technologically more advanced terminal-assisted job placement. In these pilot projects, all employment agency staff accessed their own individual terminal. They used the terminals to search and monitor vacancies, to register job descriptions, and to produce follow-up lists of unemployed and jobs. Parallel with this development, the issuing of printed job listings was reduced [18]. The pilot agencies soon became the basis for the system of job placement that AMS would come to propose.

A computer system was constructed, an inventory of facilities and work environment was conducted, and new equipment was installed. The pilot agency staff went through comprehensive training in "methods of placement with terminal"

\footnotetext{
${ }^{4}$ Search through the terminal in the form that the investigation proposed had not previously been used in other countries. The benefits of search were assessed to be primarily on the qualitative side, while the match was expected to save time.
} 
(förmedlingsmetodik med terminal). Changes in the organizational and operational procedures were implemented in the pilot agencies.

In the new pilot organization, the employment officer had to follow a work schedule that included times for the new visits of unemployed as well as their return visits, appointments with companies, monitoring of placement opportunities and following-up of the arrangements made for unemployed individuals. A system of fixed-length appointments for the unemployed was introduced. Furthermore, the need for services of each unemployed person would be assessed at each contact with the employment agency. On the one hand, this assessment formed the basis for decisions about the situation of the unemployed individual, and on the other hand, such assessments were used in the agency's overall planning of labor market programs such as education, internship positions, and introductory programs.

On the companies' side, the bigger firms engaged their own contact person at the employment agencies, who was in charge of receiving new vacant job notifications from these companies and following up their previously notified jobs [19].

The computerization of the employment agencies was a concrete step towards better conditions for the crucial process of matching jobs with the unemployed. Computerization of the employment agencies came to provide the employment services with two enhanced forms of control: First, a more accurate and updated overview of the labor market; and second, saving time in the task of matching supply and demand of labor.

The matching of work and labor is strongly associated with the emergence of a modern labor market and more specifically with industrialization, which resulted in both wage work expansion and the separation of workers and employers. In a welfare state like Sweden, the link between matching and unemployment is of central importance: it concerns issues of economic stability and social security [20]. In this context, the employment services are a national institution with the central aim to influence directly the process of "matching" in the labor market. This political commitment was manifested in defining the role of the employment agency staff in the computerized agencies, whose main task was to contribute to creating a marketplace of labor where workforce (supply) and jobs (demand) could meet.

\section{Discussion}

With the present investigation, we have aimed to clarify general political aspects of the computerization process in the Swedish welfare state in the 1960s and 1970s.

The Board of Health strived to enhance the management of a population and to upscale the scope of that management to encompass a broader range of (un)health. Automation and computerization seem to have filled two different functions in building up the new screening infrastructure. On the one hand, the automation of laboratory procedures functioned as a means to upscale the analysis capacity. Here we could argue that these technologies created and managed a historically new collective body: a healthy population. On the other hand, we could argue that these new health technologies were conservative of the orders they were part of. That is, the new screenings were based in part on older organizations of screening for disease (tuberculosis), and the main goal with the new screening and their technologies was to maintain and produce population health at an acceptable cost. 
The National Labor Market Board strived to display a control of unemployment consisting in a shorter unemployment period for the unemployed, shorter job vacancy times, and a more geographically flexible workforce: the attributes of a well functioning market machinery of supply and demand of labor. For the involved authorities, the necessary oil in this market machinery was the computerized, effective overview of, and matching between, supply and demand of work/workforce. With the computerization of the employment agencies as a tool, the authorities could intensify the shaping of the labor market as a market.

We have observed that surveillance was exerted and enhanced by computerization at three levels. It included the mobilization of a population (the improvement of which was not a goal in the computerization of employment agencies), the production and analysis of information about that population, and the actions taken by the authorities based on that information.

Our interpretation is thus that computerization afforded the Board of Health and the Labor Market Board through the employment agencies, the possibility to re-shape, technologically and organizationally, the objects of their control - (un)health and (un)employment. The same tasks could be conducted at a higher pace, and therefore possibly on a larger scale. However, we want to emphasize that these Swedish welfare institutions used computer technology primarily to improve the efficacy of their welfare procedures, and therefore as an intensification of their control of the very objects of welfare. Thus, computerization was historically a part of the redefinition of social issues in the welfare state, as those became more manageable.

Acknowledgments. We thank Handelsbankens forskningsstiftelser for supporting the research for this paper. We are also grateful to our colleagues within the project, "Precursors of the IT Nation: Computer Use and Control in Swedish Society, 1955-1985" for comments on earlier versions of the paper.

\section{References}

1. Agar, J.: The Government Machine: A Revolutionary History of the Computer. MIT Press, Cambridge (2003)

2. Annerstedt, J.: Datorer och politik: Studier i en ny tekniks politiska effekter på det svenska samhället. Cavefors, Staffanstorp (1970)

3. Waara, L.: Offentliga sektorns tillväxt. LiberLäromedel, Malmö (1981)

4. Berg, A.: Den gränslösa hälsan: Signe och Axel Höjer, folkhälsan och expertisen. Uppsala Universitet, Uppsala (2009)

5. Hälsoundersökningen i Värmland 1962-1965. Socialstyrelsen, Stockholm (1968)

6. National Archives of Sweden (Riksarkivet), Hv FLIV:1: Nilsson, G. and T. Johanson (Letter March 15, 1962)

7. National Archives of Sweden (Riksarkivet), Hv FLIV:4: Engel, A., H. Dunér, et al., (Draft of the final report) (1968)

8. Jungner, I.: Berättelsen om AutoChemist (2007), http://www.tekniskamuseet.se/1/262.html (accessed on May 17, 2010)

9. National Archives of Sweden (Riksarkivet), Hv FLIV:1: Friman, I.: P.M. angående pågående försöksverksamhet med utökad hälsokontroll i Värmlands län (Memo March 25, 1963) 
10. National Archives of Sweden (Riksarkivet), Hv FLIV:4: WHO Regional Committee for Europe, The pre-symptomatic diagnosis of diseases by organized screening procedures (Summary Report September 25, 1964)

11. Ett förslag till allmän hälsokontroll av 4-åringar. Socialstyrelsen, Stockholm (1968)

12. National Archives of Sweden (Riksarkivet), Hv FLIV:1: Friman, I.: P.M. angående uppläggning av databehandling och statistik för Värmlandsundersökningen (Memo April 14, 1964)

13. Armstrong, D.: The rise of surveillance medicine. Sociology of Health \& Illness 17(3), 393-404 (1995)

14. Arbetsförmedling med ADB-resurser. Rapport 8, Förslag till ADB-system för platsförmedling. Arbetsmarknadsstyrelsen, Stockholm (1983)

15. Arbetsförmedling med ADB-resurser. Rapport 1, En utvecklingsplan. Arbetsmarknadsstyrelsen, Stockholm (1974)

16. Hälsoundersökningar och annan förebyggande hälsovård - utvecklingstendenser [Hälsokontrollutredningen]. Socialstyrelsen / Liber, Stockholm (1978)

17. Arbetsförmedling med ADB-resurser. Rapport 2, Målstudie, verksamhet 1976/1977. Arbetsmarknadsstyrelsen, Stockholm (1976)

18. Arbetsförmedling med ADB-resurser. Rapport 7, Försöksverksamhet 1980/1981 och planering för 1981/82 m m. Arbetsmarknadsstyrelsen, Stockholm (1981)

19. Arbetsförmedling med ADB-resurser. Rapport 6, Försöksverksamhet 1979/1980 och planering under 1980/1981 m m. Arbetsmarknadsstyrelsen, Stockholm (1980)

20. Walter, L.: Som hand i handske: En studie av matchning i ett personaluthyrnings-företag. BAS, Göteborg (2005) 